This item is the archived peer-reviewed author-version of:

Beyond ethnicity : the violence in Western Uganda and Rwenzori's 99 problems

\title{
Reference:
}

Reuss Anna, Titeca Kristof.- Beyond ethnicity : the violence in Western Uganda and Rw enzori's 99 problems

Review of African political economy - ISSN 0305-6244 - 44:151(2017), p. 131-141

Full text (Publisher's DOI): https://doi.org/10.1080/03056244.2016.1270928

To cite this reference: http://hdl.handle.net/10067/1400960151162165141 
BRIEFING. Final peer-review author version; published as: Reusss, A. and Titeca, K. (2016) "Beyond ethnicity: the violence in Western Uganda and Rwenzori's 99 problems", Review of African Political Economy, ISSN 0305-6244: online first.

http://www.tandfonline.com/doi/full/10.1080/03056244.2016.1270928

\section{Beyond ethnicity: the violence in Western Uganda and Rwenzori's 99 problems}

Anna Reuss ${ }^{\mathrm{a}, \mathrm{b}}$ and Kristof Titeca ${ }^{\mathrm{a}}$

${ }^{a}$ Institute for Development Studies and Management, University of Antwerp, Antwerp, Belgium; 'bepartment of Conflict and Development Studies, Ghent University, Ghent, Belgium

CONTACT Kristof Titeca kristof.titeca@uantwerp.be

\section{SUMMARY}

In the Rwenzori region, a range of historical, socio-economic and political tensions have in past years resulted in a series of deadly clashes between different ethnic communities. Patronage politics of recognition of cultural kingdoms and district creation critically drives the manifestation of these tensions in ethnic violence, especially in the context of electoral contest.

\section{Introduction}

During violence in July 2014, over 100 people were killed in the Rwenzori region on the border with the Democratic Republic of Congo (DRC) in western Uganda. ${ }^{1}$ The violence was started by small groups, mainly youth, of the Bakonzo ethnic group, which attacked police and army posts in three districts. This in turn led to revenge attacks by members of other ethnic groups, and to brutal counter-security operations against the Bakonzo (HRW 2014). After the February 2016 general elections, clashes in the wider region left more than 50 dead, hundreds of homes razed and thousands displaced (HRW 2016). Government explanation in both instances focused on the clear ethnic overtones of the clashes, and in 2016 prominently singled out alleged ethno-nationalist mobilisation among the Bakonzo, the majority ethnic group in the region, as responsible for the violence. This briefing aims to show how ethnicity is an outward layer beneath which there is a host of historical, social-economic and political conflict dynamics - a process we have titled 'Rwenzori's 99 problems'. It argues that government failure to effectively address the root causes of long-standing tensions in the Rwenzori region has led to resurgent violence often expressed in ethnic terms. The range of conflict drivers is similar to those plaguing communities across Uganda: they revolve around competition over the use and ownership of land, access to public office, natural resource exploitation, and a burgeoning youth population in the face of development challenges, and are fuelled by securitisation, and patronage politics, especially in the context of electoral contests. In the next sections, we unpack these various root causes. 


\section{Historical roots: oppression, marginalisation and resistance}

The Rwenzori region comprises three districts - Kasese, Bundibugyo, and Ntoroko - at the foothills of the Rwenzori mountain range that constitutes Uganda's natural border with the DRC. The districts of Kasese and Bundibugyo are at the heart of the Rwenzori region, and are inhabited mainly by the Bakonzo, the Basongora and the Bamba ethnic groups.

The Rwenzori region has a long history of armed resistance, revolving around two interlinked key elements: the struggle of minority ethnic groups against a majority, and the recognition of cultural institutions or kingdoms.

In the Rwenzori heartland, a minority tribe faces the overwhelming dominance of a majority ethnic group. In Kasese District, the Bakonzo are the largest ethnic group, with the Basongora and the Banyabindi ethnic groups being the minority. The cattle-keeping Basongora were the original inhabitants of the area before the peasant Bakonzo migrated to the area, and today the former make up only $1 \%$ of the population. The Basongoro and Banyabindi feel displaced by the Bakonzo and feel that their collective identity and cultural institutions have been undermined by years of oppression - "we are victims of cultural genocide" (CCFU 2014a, 12). In Bundibugyo District, the role of the Bakonzo role is reversed: they present a minority against a majority of the Bamba.

The struggle between a minority and a majority group date from the precolonial times, when the Bakonzo, the Basongora and the Bamba all were subjects of the Tooro kingdom, situated in Fort Portal. The complexity of colonial rule accentuated the problem of tribe and tribal identity; the Bakonzo were seen as labourers; the Tooro were given more clerical work. Much of the ethnic differentiation and a perception of the Batooro as oppressors dates from this period (CCFU 2014a, 12). During the colonial rule, the Bakonzo launched a first armed rebellion against the Tooro kingdom. ${ }^{2}$ Afterwards, the Rwenzururu rebellion launched in 1962 sought independence from Tooro and the establishment of a Rwenzururu kingdom. As Doornbos $(1970,1069)$ argued, the Rwenzururu movement was an attempt to redress 'inequalities in the distribution of power; in access to the political centre for the allocation of benefits; in wealth and welfare; and in dignity and social status'. In 1974, the regime of Idi Amin created Rwenzori District for Bakonzo (roughly Kasese District today), Semliki District for Bamba (Bundibugyo today) and Kabarole District for the Batooro. However, the Rwenzururu rebellion's aspiration to an independent state was not addressed, and Rwenzururu leaders were excluded from the district leadership structure (Syahuka-Muhindo and Titeca 2016). In 1982, a political settlement formally ended the low-intensity rebellion. Rwenzururu forces laid down their arms in return for a degree of local autonomy and the integration of their leaders in the Kasese administration. However, some secessionist Rwenzururians who rejected this reconciliation took up arms again, by forming the National Army for the Liberation of Uganda (NALU). In 1989, NALU fighters carried out attacks, killing some local council leaders in the highlands of Kasese. In 1993, NALU was defeated and its leader killed (Syahuka-Muhindo and Titeca 2016).

This was not the end of the armed resistance: NALU remnants later joined the antigovernment Allied Democratic Forces (ADF) that destabilised the Rwenzori region between 1996 and 2000. By 2001, ADF/NALU no longer posed any serious threat to the Ugandan 
government. The remaining parts of the rebel group retreated to DRC (Titeca and Vlassenroot 2012, 160; Titeca and Fahey 2016). Nevertheless, the history of rebellion in the area still is an important frame through which contemporary events are understood. This is particularly important in the light of continuing tensions between the majority and the minority ethnic groups, which are discussed further in the next section.

\section{The defining role of ownership and use of land}

One way in which the majority-minority tensions have historically been defined is through competition over the use and ownership of land, particularly between the agriculturalist Bakonzo and the Basongora herders. The 'traditional' tensions between the pastoralist Basongoro and cultivating Bakonzo are aggravated by unclear land titles and a general scarcity of habitable land and grazing grounds (New Vision 2007). The gazetted areas of Rwenzori and the Queen Elizabeth National Parks cover large swathes of the district. For a long time, the national parks have been sources of contention between the people neighbouring them, the encroachers and the government authorities (CARE 2009).

Moreover, tensions around perceived preferential treatment of particular groups in the area contribute to a mutual sense of marginalisation of both minority and majority ethnic groups. The minority Basongora feel marginalised and dominated by the Bakonzo majority, while many Bakonzo harbour a sense that the Basongora cattle-keepers are favoured in land allocation and development projects (CCFU 2014a, 10). Such situations have led to violent clashes between the Basongora and the Bakonzo. For example, in 2008 over 80 Basongora houses were set on fire, and over 500 cattle killed following the eviction of Bakonzo cultivators from a disputed 200-hectare area of land (Musinguzi et al. 2014, 4). ${ }^{3}$

Today, Kasese is the fifth most populous district of Uganda, aided by a stream of migrants and immigrants in the region (RFPJ 2016a, 5). ${ }^{4}$ The combination of historical tensions between cultivators and cattle-keepers, rapid population growth, and the scarcity of habitable land make fierce competition over land inevitable. Moreover, in recent years, oil prospects in the Albertine Rift have led to speculative land deals and a sharp rise in cases of land-grabbing (KRC and RFPJ 2012, 21).

\section{The role of the national government and increased tensions}

National political calculations came to play a central role in this situation, and further fuelled the tensions. Crucially, since the re-establishment of multiparty elections, the region has largely voted for the opposition. In this situation, the recognition of kingdoms and the creation of districts has become hard currency in (strategies of) vote winning for the National Resistance Movement (NRM) government: given that both institutions - kingdoms and districts - create a whole range of public jobs and guarantee financial transfers from the national level, they have become central elements in President Yoweri Museveni's regime's patronage politics. It has been widely shown how the creation of districts has traditionally been used for electoral reasons (Green 2010), and the recognition of kingdoms has been used in a similar manner. As we will show below, instead of solving existing tensions, the creation of new districts and the recognition of new kingdoms have instead further entrenched and 
fuelled them: ethnic identities have become further crystallised, and tensions between majority and minority groups have increased.

\section{The recognition of kingdoms}

When the Rwenzururu rebels laid down arms, the Rwenzururians did not abandon the pursuit of a Rwenzururu kingdom. In 1993, the government restored traditional kingdoms as cultural institutions in the Traditional Rulers Act (Government of Uganda 1993). The legal recognition of cultural leaders is enshrined in the 1995 Constitution (CCFU 2014b). But the Rwenzururians' claim to a recognised Rwenzururu kingdom, which they continued to press for over the following decade, continued to be rejected by government. As a result of this, the opposition (and more particularly the Forum for Democratic Change [FDC]) strongly grew in popularity, resulting in a number of harsh electoral battles (Titeca 2007).

In order to increase its popularity in the region, the government recognised the Obusinga bwa Rwenzururu (OBR) kingdom in 2009 (RFPJ 2014) and in the following year crowned Charles Mumbere, the Mukonzo ${ }^{5}$ son of an erstwhile Rwenzururu rebellion leader, king. But Kasese District again voted for the opposition in the 2011 elections and, rather than pacifying the region, the recognition of the OBR kingdom further aggravated existent tensions over domination and marginalisation between and within ethnic groups. Because the Rwenzururu king is a Mukonzo, minority tribes regard the OBR as a representation of the Bakonzo people, thus institutionalising the minority groups' marginalisation by the majority Bakonzo (CCFU 2014a, 9-11). This sense of cultural domination through the Bakonzo and their language to some feels similar to the cultural oppression the Rwenzori region's tribes once experienced under the Batooro (Daily Monitor 2016c). A report on the 2014 clashes (Musinguzi et al. 2014) describes how minorities consider the attitude of the Bakonzo to be 'intended assimilation and imperialism' through for example the adoption of Bakonzo names, the OBR flag in the communities, and the claim that the Basongora are only a clan group among the Bakonzo (Musinguzi et al. 2014, 3).

Aggravated grievances over marginalisation of non-Bakonzo gave rise to a growth of ethno-nationalism in the region (CCFU 2014a, 15, 30): also other ethnic groups (more particularly the Basongora and the Bamba) advocated for government recognition of (re)invented cultural institutions. Further fuelling these tensions is the fact that control over a kingdom gives access to the government's patronage network: besides legally prescribed entitlement to government allowances, their potential for popular mobilisation at local level commonly grants kingdoms additional financial and material benefits.

In this context, symbolic issues - such as royal visits or ceremonies - have become explosive. In 2012, violence erupted between Bamba and Bakonzo when the Rwenzururu king visited Bwamba County in Bundibugyo, and hissed a Rwenzururu kingdom flag. A month later, the Basongora in Kasese District crowned their own king, irrespective of lack of government recognition, triggering clashes between Basongora and Bakonzo youth who stole the Basongora flag and royal drum (Daily Monitor 2012a; KRC and RFPJ 2012, 13). Yet another month later, the Banyabindi minority in Kasese District secretly also installed a cultural leader. In October 2012, tensions flared again between Bakonzo and Basongora, leaving cattle mutilated and fields razed (Daily Monitor 2012b). In sum, instead of calming 
down the relations between the various ethnic groups, the recognition of the Bakonzo kingdom further fuelled these tensions.

\section{District creation}

To avoid the establishment of ever more cultural kingdoms, district creation has been the primary government response to ethno-nationalist sentiments at local level. As mentioned above, Idi Amin in 1976 sought to appease Rwenzururu leaders by dividing Kabarole District into three, essentially giving to each of the Bakonzo, the Bamba, and the Batooro their own district. Since 2002, the number of Uganda's districts has doubled: Justified by the country's decentralisation policy, new district creation has in many cases been primarily a critical tool of patronage for government to secure votes in elections (Green 2010), while leaving substantive development challenges unaddressed.

As mentioned above, the OBR was recognised in the lead-up to the 2011 elections in an attempt to swing Kasese District's past opposition votes towards government. Yet, Kasese's persistent opposition vote and the July 2014 violence underscored the intricacies and explosive potential of the national government's approach to mobilisation of votes at local level.

The government sought to address ethnic tensions expressed in the 2014 and 2016 violence with the creation of new districts along ethnic lines. But, like kingdom recognition, district creation feeds into existent sentiments of domination and marginalisation, and further crystallises ethnic identities, giving rise to new conflicts (Green 2008).

This became particularly clear in Bundibugyo. This district is dominated by the Bamba, but youth of the Bakonzo minority had been held responsible for instigating violence in 2014. In the lead-up to the 2016 elections, the President promised to carve a highland district out of Bughendera County for the Bakonzo in an attempt to secure the Bakonzo vote in Bundibugyo (Observer 2016a). This buy-off attempt was underscored by the OBR king's brother, a long-time opposition politician, switching political allegiance and running for the county parliamentary seat in the district-to-be (Observer 2016b). But the promise of a new Bakonzo District heightened tensions in Bundibugyo. The victory of Bughendera County's parliamentary seat by the Rwenzururu king's brother in the 2016 elections was thus symbolic of the Bakonzo minority's assertion in Bundibugyo and an expansion of the OBR kingdom's influence. After the polls, clashes in Bughendera left at least 30 dead, hundreds of houses razed, and thousands displaced (New Vision 2016b; 2016e). In sum, while district creation might bring political gain for the national government and ruling party, it creates a range of tensions on the ground.

\section{Kingdoms, youth, and disruption of social order}

The creation of the OBR did not only create tensions between the Bakonzo and other ethnic groups; segments of the Bakonzo also opposed the new kingdom. ${ }^{6}$ Tensions emerged between those who were very actively involved in the rebellion (the freedom fighters, mainly residing in the mountains) and those who remained on the sidelines - mainly Bakonzo residing in the lowland, who are known to co-exist more easily with other ethnic groups (CCFU 2014a, 11). Second, tensions emerged between the 'traditional' and 'new' governance structures. Traditionally, political and social organisation was based on clans, councils of 
elders, and on ridge leaders who govern Bakonzo life in the mountain ridges of the Rwenzori (Mugisha and Infield 2012, 245). Under the 'reinvented', centralised kingdom, the OBR has established a "new parallel governance structure of traditional but "modern" educated leaders in each sub-county' (CCFU 2014a, 15). This sidelines ridge leaders and councils of elders, despite the fact that they are in closer contact with the people. Thus, the establishment of the OBR led to intra-communal tensions surrounding the legitimacy of the reinvented cultural leadership, and at the same time weakened traditional institutions such as the ridge leaders, who were considered effective in the resolution of localised conflicts (Sarmiento et al. 2015, 699).

Disruption of the established social order in rural communities is also driven by the rapidly growing youth population and unaddressed development challenges, most importantly high youth under- and unemployment (Magelah and Ntambirweki-Karugonjo 2014). This has contributed to rising levels of crime and an erosion of traditional mechanisms of conflict resolution through elders and ridge leaders (CCFU 2014a, 19; RFPJ 2016b). Youth, some of them organised in vigilante groups, were identified as the main perpetrators of attacks in recent outbreaks of violence (RFPJ 2016b). On a regular basis, the government accuses members of the Rwenzururu kingdom government of mobilising a Bakonzo youth militia for attacks (Daily Monitor 2014b; Daily Monitor 2016b; East African 2016a). More than 500 youths who were arrested and arraigned before military courts in July 2014 were eventually released, and granted 'amnesty' without due legal process or a demobilisation programme (RFPJ 2016a). Rather, many of these youth were recruited into the crime preventers, a controversial police-trained, militia-like force that heightened nationwide fears of election violence in the lead-up to the 2016 polls. In the series of deadly clashes in the region following the elections, youth again were the main instigators of violence (New Vision 2016a).

\section{Government response to the violence and the role of security forces}

The government's response to the Rwenzori violence in early 2016 was twofold. First, a flurry of mediation efforts ensued (New Vision 2016h). President Museveni engaged with delegations of local political, cultural and religious leaders (New Vision 2016g). On a tour of the region, Museveni brokered a symbolic peace deal between the Bamba and the king of Rwenzururu, who both denied their kingdoms' involvement in the clashes (New Vision 2016i).

Second, the government engaged through a strong militaristic response, which has been a dual driver of stability and fragility. The fact that police and army personnel and installations were the first targets in the outbreaks of violence in 2014 and 2016 points to existing popular grievances over the role of state security forces in the region (New Vision 2016b). President and police have blamed grassroots intelligence officers for not only failing to detect the violence, but also of contributing to local tensions through arbitrary arrests and abuse of office (Daily Monitor 2014a; New Vision 2016d; Tabaire 2014). Heavily armed police were deployed to contain clashes, but some units soon had to be withdrawn, as local political leaders particularly blamed the notorious Flying Squad for fuelling further unrest (Daily Monitor 2016e; New Vision 2016c). In early March 2016, an officer of the police's 
militarised Field Force Unit was filmed shooting an unarmed civilian, sparking national outrage (Daily Monitor 2016a). ${ }^{7}$ One month later, a Flying Squad officer shot and killed a Rwenzururu traditional guard (Daily Monitor 2016d). As often in Museveni's Uganda, the military came in to salvage the situation. The deployment of the army into Kasese and the mountains of the Rwenzori in April 2016 put a temporary end to the violence and restored a sense of calm. However, it is unnecessary to state that a 'military solution treats symptoms, not causes' (MRG 2016).

Third, and in line with the above point on district creation, six months after the elections the government endorsed the creation of four new districts out of Kasese District. A plan to carve out new districts to counter a sense of Bakonzo domination had repeatedly been tabled since 2010 (Daily Monitor 2013), but failure to agree on how the new districts would be carved out - and how many of them there would be ${ }^{8}-$ had stalled their creation (KRC and RFPJ 2012, 23). Following the 2016 elections, which were overwhelmingly won by the opposition in Kasese District, and particularly following the consequent post-electoral violence, the split of the district was retabled for discussion in order to counter these two dynamics. The local ruling party caucus and Crispus Kiyonga, the ousted long-time NRM Member of Parliament and cabinet minister (and vocal opponent of the kingdom), endorsed the creation of new districts in a bid to alleviate tensions between different groups. In October, President Museveni approved the division of Kasese into four new districts: Bwera, Hima, Kasese, and Katwe (Daily Monitor 2016f). The OBR and the newly elected opposition parliamentarians from Kasese District opposed the split, regarding it as an attempt by government to weaken their power. At the Rwenzururu kingdom's $50^{\text {th }}$ anniversary celebrations the following week, the OBR criticised the new district creation as an attempt by illegitimate 'self-seekers' to undermine the kingdom and the elected district council, since the 2016 elections had been dominated by the opposition FDC (New Vision 2016j). ${ }^{9}$

Peace and justice remain unaddressed in the region. No substantive reconciliation efforts have been pursued or policy changes effected to address long-standing grievances over a perceived government neglect of the region (East African 2016b). Up till the present, no investigations have been conducted into mass graves discovered in 2014 (East African 2016c). Hundreds of youths brought before military tribunals over the violence have neither been given due legal process nor a demobilisation programme after release (RFPJ 2016a).

\section{Conclusion}

The government's reaction to the recent tensions in the Rwenzori region has consistently been to blame local political and cultural leaders for instigating ethnic conflict. In response to the 2014 attacks, the police spokesperson for example argued how 'There is a tribal conflict,' while the government, in response to the 2016 killings, alleged that (segments of) the Bakonzo-led Rwenzururu kingdom in Kasese sought to create an independent 'Yiira Republic' (New Vision 2016f) together with their tribesmen in Congo popularly known as the Nande. ${ }^{10}$

This briefing aimed to show how ethnic tensions are only the outward layer of the conflict, and how instead various other layers are crucial thriving factors: historically, the differentiation and opposition between majority and minority groups can be traced back to 
the colonial intervention and continues to play an important role. This became further pronounced through increasing (im)migration tendencies, tensions around land, and increasing youth unemployment. The national government's interventions played a crucial role in further fuelling these tensions: districts and kingdoms are popular pawns in the political game of vote winning. Similarly, local elites manipulate communal identities to ensure their control over voters and resources. Rather than bringing people together, the recognition of the cultural institutions and the politics of new district creation has further emphasised division, which make many claim that they have led to a deterioration of conflicts, by further crystallising ethnic identities and the consequent tensions surrounding them, both between different ethnic groups and within them. While the government's securitisation approach helps to temporarily stop the violence, it also further contributes to it.

What happens in this process is an 'ethnicisation of politics and politicisation of ethnicity for political leverage and expediency' (RFPJ 2016b, original emphasis). However, the unclear process of establishing a kingdom, contested district creation, and the poor management of the consequences, in turn magnify existing tensions and conflict (CCFU 2014a, 30). What has happened in this process is that the various actors - minority/majority ethnic groups, the kingdoms, local political leadership, and the state - have continuously focused on short-term gain of winning votes or gaining control over public resources associated with kingdoms and districts, yet they have equally added fuel to the slow-burning fire of inter- and intra-communal tensions, which overall has led to an explosive situation in which potentially marginal events achieve highly symbolic significance.

The violence in the Rwenzori region offers important lessons for the rest of Uganda. Rwenzori's '99 problems' are not unique to the communities in the region. All of the root causes of the deadly violence in western Uganda are key elements of the overall political culture in Uganda: land conflicts, youth unemployment, ethnic tensions, perceptions of marginalisation, traditional institutions, the involvement of security agencies, political manipulation and the other factors mentioned above are found in districts and communities all over Uganda. The Rwenzori case particularly highlights the high risks of ethnic violence in Uganda implied in the current practice of addressing inter- and intra-communal grievances primarily through patronage politics of district and kingdom creation in pursuit of short-term gains.

\section{Disclosure statement}

No potential conflict of interest was reported by the authors.

\section{Notes on contributors}

Anna Reuss is a joint $\mathrm{PhD}$ candidate at the University of Antwerp Institute for Development Studies and Management, and in the Department of Conflict and Development Studies at Ghent University. Her doctoral research focuses on regime stability and the security sector in Uganda. Based in Kampala, Uganda, she works as an independent analyst of political, security and integrity risks in Eastern Africa. Email: anna.e.reuss@gmail.com. 
Kristof Titeca is an assistant professor at the University of Antwerp Institute for Development Studies and Management. He has published extensively on conflict and governance in Central and Eastern Africa. Email: kristof.titeca@uantwerp.be.

\section{References}

CARE Uganda. 2009. Conflict-sensitive Conservation: Field Report from Queen Elizabeth National Park. London: International Institute for Sustainable Development.

CCFU [Cross-Cultural Foundation of Uganda]. 2014a. Managing Inter-cultural Conflict in the Rwenzori Region: Interventions and Aspirations. Kampala: CCFU.

CCFU. 2014b. Legal Instruments Related to Culture and Cultural Institutions in Uganda. December. Kampala: CCFU.

Daily Monitor. 2012a. “The Basongora Royal Drum and Flag Taken Captive.” July 11. Accessed October 15, 2016 at http://www.monitor.co.ug/News/National/The-Basongora-royal-drum-and-flagtaken-captive/-/688334/1450956/-/gag11cz/-/www.qatarairways.com/\%2523.

Daily Monitor. 2012b. "Cattle Attacked in Fresh Kasese Clashes." October 8. Accessed October 15, 2016 at http://www.monitor.co.ug/News/National/Cattle-attacked-in-fresh-Kasese-clashes/6883341527438-38n4m6/index.html.

Daily Monitor. 2013. "RDC Tells Kasese to Forget Split of District." March 2. Accessed October 15, 2016 at http://www.monitor.co.ug/News/National/RDC-tells-Kasese-to-forget-split-ofdistrict/688334-1708292-21 mp61/index.html.

Daily Monitor. 2014a. "Where Were My Spies? Museveni Asks.” July 9. Accessed October 15, 2016 at http://www.monitor.co.ug/News/National/Rwenzori--Where-were-my-spies--Museveniasks/688334-2376830-q1sr3v/index.html.

Daily Monitor. 2014b. "New Rebel Group Sets Up Base in Rwenzori." 16 October. Accessed October 15, 2016 at http://www.monitor.co.ug/News/National/New-rebel-group-sets-up-base-inRwenzori/688334-2488148-k3man4z/index.html.

Daily Monitor. 2016a. "How Police Boss was wounded in Kasese Attacks." March 13. Accessed October 15, 2016 at http://www.monitor.co.ug/News/National/Police-boss-was-wounded-Kaseseattacks/688334-3115492-slkua5z/index.html.

Daily Monitor. 2016b. "Election Malpractice Caused Kasese Violence.” March 15. Accessed October 15, 2016 at http://www.monitor.co.ug/News/National/Election-malpractice-caused-Kasese-violence-Rwenzori-leaders/688334-3117002-vvbv9jz/index.html.

Daily Monitor. 2016c. "Tracing Ethnic Conflicts in the Rwenzori." March 20. Accessed October 15, 2016 at http://www.monitor.co.ug/Magazines/PeoplePower/689844-3124160-5n7olm/index.html.

Daily Monitor. 2016d. "UPDF Withdraw Royal Guards from Rwenzururu Kingdom.” April 6. Accessed October 15, 2016 at http://www.monitor.co.ug/News/National/UPDF-withdraws-royalguards-Rwenzururu-kingdom/688334-3148358-1281irz/index.html.

Daily Monitor. 2016e. "Police Flying Squad Suspends Operation in Rwenzori." April 13. Accessed October 15, 2016 at http://www.monitor.co.ug/News/National/Police-flying-squad-suspendsoperation-Rwenzori/688334-3157224-946osqz/index.html. 
Daily Monitor. 2016f. "Kasese to be Split into Four Different Districts." October 13. Accessed October 15, 2016 at http://www.monitor.co.ug/News/National/Kasese-to-be-split-into-four-differentdistricts/688334-3415580-ns2qeb/index.html.

Doornbos, Martin. 1970. "Kumanyan and Rwenzururu: Two Responses to Ethnic Inequality." In Protest and Power in Africa, edited by I. Rotberg and A. Mazrui, 1088-1136. New York: Oxford University Press.

East African. 2016a. "Uganda Parliament to Probe Rwenzori Violence." April 9. Accessed October 15, 2016 at http://www.theeastafrican.co.ke/news/Uganda-Parliament-to-probe-Rwenzori-violence-//2558/3152500/-/k5eq6x/-/index.html.

East African. 2016b. "Museveni Denies Sidelining Restive Region, But Critics Say Record Points to Disparities." April 17. Accessed October 15, 2016 at http://www.theeastafrican.co.ke/news/Musevenidenies-sidelining-restive-Kasese-region/2558-3162650-nv3djg/index.html.

East African. 2016c. "Land Issues and Poverty at Centre of Rwenzori Crisis." April 17, 2016. Accessed October 15, 2016 at http://www.theeastafrican.co.ke/news/Land-issues-and-poverty-atcentre-of-Rwenzori-crisis-/2558-3162648-12355byz/index.html.

Government of Uganda. 1993. The Traditional Rulers (Restitution of Assets and Properties) Act. Entebbe: Government Printer.

Green, Elliot. 2008. "Decentralisation and Conflict in Uganda." Conflict, Security \& Development 8 (4): 427-450.

Green, Elliot. 2010. "Patronage, District Creation, and Reform in Uganda." Studies in Comparative International Development 45 (1): 83-103.

HRW [Human Rights Watch]. 2014. "Uganda: Violence, Reprisals in Western Region.” November 5. Accessed October 15, 2016 at https://www.hrw.org/news/2014/11/05/uganda-violence-reprisalswestern-region.

HRW. 2016. "Uganda: Lethal Response to Killings". July 15. Accessed October 15, 2016 at https://www.hrw.org/news/2016/07/15/uganda-lethal-response-killings.

KRC [Kabarole Research and Resource Centre] and RFPJ [Rwenzori Forum for Peace and Justice]. 2012. "Stuck in the Mist: Contextual Analysis of the Conflicts in the Rwenzori Region." December. Fort Portal: KRC and RFPJ.

Magelah, Peter and Barbara Ntambirweki-Karugonjo. 2014. "Youth Unemployment and Job Creation: Opportunities and Challenges." Infosheet No. 26. Kampala: Advocates Coalition for Development and Environment.

MRG [Minority Rights Group]. 2016. "Minority Rights Group calls on Uganda Government to Investigate Cause of Escalating Violence in Rwenzori Region." April 4. Press release. Accessed October 15, 2016 at http://minorityrights.org/2016/04/04/mrg-calls-on-uganda-government-toinvestigate-cause-of-escalating-violence-in-rwenzori-region/.

Mugisha, Arthur and Mark Infield. 2012. "The Role of Cultural Values in the Management and Conservation of Rwenzori and Lake Mburo National Parks in Uganda." In Rethinking Protected Areas in a Changing World, Proceedings of the 2011 George Wright Society Conference on Parks, Protected Areas, and Cultural Sites, edited by Samantha Weber, 244-251, Hancock, Michigan: George Wright Society. Accessed October 15, 2016 at http://www.georgewright.org/gws2011_proceedings.pdf. 
Musinguzi, Francis, Primus Bahigi, Christopher Busiinge and Francis Tuhaise. 2014. Rwenzori Tribal Clashes: An Aftermath Narrative. July 8. Fort Portal: Kabarole Research and Resource Centre Rwenzori Forum for Peace and Justice.

New Vision. 2007. "Who are the Basongora?" June 30. Accessed October 15, 2016 at http://allafrica.com/stories/200707020962.html.

New Vision. 2016a. "Armed Youth Attack Taxi in Bundibugyo District”, March 29.

New Vision. 2016b. "Museveni Vows to get Bundibugyo Attackers." March 29.

New Vision. 2016c. "Police, Army Explain Mumbere Palace Shooting." April 5.

New Vision. 2016d. "Report Blames Intelligence Officers for Bundibugyo Attacks.” April 7.

New Vision. 2016e. "13 Men Charged over Bundibugyo Killings.” April 8.

New Vision. 2016f. “Uganda Cultural Leaders Visit Rwenzururu King.” April 11.

New Vision. 2016g. "Kasese FDC Leaders Meet Museveni, Reject Yiira State.” April 12.

New Vision. 2016h. "Rwenzori Clashes can only be solved through Dialogue, Says Mukula." April 14.

New Vision. 2016i. "Rwenzururu, Bamba Kings Sign Peace Agreement." April 16. Accessed October 15, 2016 at http://www.newvision.co.ug/new_vision/news/1422286/rwenzururu-bamba-kings-signpeace-agreement.

New Vision. 2016j. “Omusinga Warns Against Splitting Kasese.” October 24.

Observer (Kampala). 2016a. "Museveni 'Okays' Bakonzo District.” January 20. Accessed October 15, 2016 at http://allafrica.com/stories/201601200310.html.

Observer (Kampala). 2016b. "Ex-MP Kibanzanga - Why I Crossed from FDC to NRM." January 27. Kampala. Accessed October 15, 2016 at http://allafrica.com/stories/201601271039.html.

Pennacini, Cecilia. 2008. "The Rwenzori Ethnic Puzzle." In Histories and Cultures of an African mountain, edited by C. Pennacini and Hermann Wittenberg, 59-97, Kampala: Fountain Publishers.

RFPJ [Rwenzori Forum for Peace and Justice]. 2014. Skewed Interpretation of the Law on Cultural Institutions Contributing to Inter-cultural Tensions in the Rwenzori Region. October. Fort Portal: RFPJ.

RFPJ. 2016a. Annual Report 2015. July. Fort Portal: RFPJ.

RFPJ. 2016b. Petition to Members of Parliament and District Chairpersons-elect on 2016 Geo-ethnopolitical Violence in the Rwenzori Region. April. Fort Portal: RFPJ.

Sarmiento, F., E. Bernbaum, J. Brown, J. Lennon, and S. Feary. 2015. "Managing Cultural Features and Uses." In Protected Area Governance and Management, edited by G. L. Worboys, M. Lockwood, A. Kothari, S. Feary and I. Pulsford, 685-714. Canberra: ANU Press.

Syahuka-Muhindo, Arthur and Kristof Titeca. 2016. "The Rwenzururu Movement and the Struggle for the Rwenzururu Kingdom in Uganda". IOB Discussion Papers 2016 (01). Antwerp: Institute of Development Policy and Management.

Tabaire, Bernard. 2014. "Here is one Angle Reporters Could Follow in Covering Rwenzori Rage." July 11. Kampala: Uganda Journalists' Resource Centre. Accessed October 15, 2016 at http://ugandajournalistsresourcecentre.com/one-angle-reporters-follow-covering-rwenzori-rage/. 
Titeca, Kristof. 2007. "The Politics of Civil Society Organisations in Arua and Kasese, Uganda." PhD dissertation, Ghent University.

Titeca, Kristof and Daniel Fahey. 2016. "The Many Faces of a Rebel Group: the Allied Democratic Forces in the Democratic Republic of the Congo." International Affairs 92 (5): 1189-1206.

Titeca, Kristof and Koen Vlassenroot. 2012. "Rebels without Borders in the Rwenzori Borderland? A Biography of the Allied Democratic Forces." Journal of Eastern African Studies 6 (1): 154-176.

1 The final version of this paper was submitted on 1 November 2016, before the clashes of late November 2016 in the Rwenzori region. For this reason, the briefing does not deal with these events.

${ }^{2}$ The Abayora revolt was a protest against the imposition of colonial rule on the Bakonzo, and on the cultural oppression of Tooro, in addition to forced labour and taxation (Syahuka-Muhindo and Titeca 2016).

${ }^{3}$ See http://ugandaradionetwork.com/story/basongora-bakonzo-clash-over-land-evictions.

${ }^{4}$ This (im)migration is related to a variety of issues, such as labour migrants who seek opportunities in Kasese's mining industry and the oil sector, but also Ankole cattle-herders and refugees from DRC.

${ }^{5}$ Mukonzo is the singular of Bakonzo.

${ }^{6}$ Long-time defence minister Crispus Kiyonga, a Mukonzo from Kasese, was one of its most vocal critics.

${ }^{7}$ See https://www.youtube.com/watch?v=YVBATs-uIZw.

${ }^{8}$ And thus who would control more and better habitable land, and whether the Basongora minority would gain a majority in any of the new districts.

9 Heightened tensions between the kingdom and government became visible at the ceremonial grounds: royal guards denied access to police, including personal guards of politicians (New Vision 2016j).

${ }^{10}$ See Pennacini (2008) for history, relations and identity politics of the Nande and Bakonzo. 